\title{
Abstract
}

\section{Research Protocol for Homeopathic Treatment of Congenital Zika virus Infection}

\author{
Maria Filomena Xavier Mendes 1*; Romeu Carillo Jr²; Domingos José Vaz do Cabo3; Maria \\ Solange Gosik'; Renata Rodrigues Garcia Lino ${ }^{5}$; Raquel Bruno Kalile6; Davisson Tavares ${ }^{7}$ \\ Giselle Iannarella Lacerda8; Maria Helena Capobianco9; Sandra Motta Martins ${ }^{10}$; Paulo \\ Guilherme Leandro de Oliveira'11; Leticia M Werneck dos Santos ${ }^{12}$
}

1-Master in Neurology - UFRJ; Postgraduate in Neuropediatrics, Homeopathy Physichian, Abrah, RJ, Brazil 2-Head of Homeopathy Clinic - Hospital do Servidor Público Municipal de São Paulo - HSPM; Advisor of extension courses of Abrah in Brazil- romeucarillo@gmail.com

3-Master in Public Health - FIOCRUZ; Pediatric, Homeopathy and family and community medicine physichian, RJ, Brazil - domingosjvcabo@gmail.com

4-Pediatric and Homeopathy physichian; National Coordinator of Abrah in Brazil - msgosik@uol.com.br 5-Master in Public Health , Homeopathy physichian; supervisor of homeopathy ambulatory of Abrah , RJ, Brazil - renatalino2@gmail.com

6-Homeopathy physichian; General supervisor of homeopathy ambulatory of Abrah in RJ, Brazilraquelbk@terra.com.br

7-Homeopathy and allergy physichian (ABRAH) , - davissontavares@yahoo.com.br

8-Pediatry and Homeopathy physichian (ABRAH), Head of the Neonatology Department of Maternity Carmela Dutra, Rio de Janeiro, Brazil - gilacerda@terra.com.br

9- Pediatric and Homeopathy physichian (ABRAH) RJ, Brazil - capobianco.mh@hotmail.com

10-Homeopathy physichian, Physiatrist (AFR), RJ, Brazil - sandradamotta@yahoo.com.br

11-Homeopath, Professor and Researcher, CIBIO (Center of Studies in Biodiversity and Genetic Research), Evora University, Portugal - oliveira@uevora.pt

12-Homeopathy and family and community medicine physichian, RJ, Brazil- lelawerneck@gmail.com

* filoabrah@yahoo.com.br - https://orcid.org/0000-0002-4785-8237

Background The Zika virus (ZIKV) is a flavivirus and the human disease caused by this virus has been described in the Americas in 2015. ZIKV has been identified as an etiological agent of acute exanthematous disease in Brazil. In the same year, an epidemic of microcephaly with images suggestive of congenital infection raised the suspicion of a relationship between these alterations and ZIKV infection. Epidemiological and histopathological studies point to a strong relationship between prenatal Zika virus infection and microcephaly. Newborns with microcephaly, may also present auditory and visual changes, seizures and severe neurodevelopmental impairment. In 2016, the World Health Organization (WHO) declared Zika virus (ZIKV) infection a public health emergency of international concern. Aims Clinical observation in the ambulatory school of ABRAH (Brazilian Association of Recycling and Homeopathy Assistance) of patients with encephalopathy of various origins, using the medicine Helleborus niger as equalizer of the NS (Nervous System), as described in the Complex Systems of Carillo, shows improvement in motor, cognitive and seizure disorders. Based on this observation, we propose to use this method in patients with ZIKV congenital infection. Methodology To evaluate 15 patients in follow-up at the AFR (Fluminense Rehabilitation Association), through homeopathic anamnesis, clinical, diathesic, biotypological and temperamental classification. The Gross Motor Function Classification System (GMFCS) will be used. All patients will receive Helleborus niger $6 \mathrm{Ch}$ daily for 6 months. Results and discussion This study was forwarded to the research ethics committee and will begin in July 2019. Will be evaluated the use of Helleborus niger in patients with congenital infection by ZIKV, as equalizer of NS. The expected result is overall neurological improvement. Conclusion Helleborus 
Available online at www.highdilution.org

niger, probably stimulating self-regulation through uninjured neurological pathways, will promote autopoiesis and construction of new programs of action, and will enable the improvement of patients with congenital ZIKV infection.

KEYWORDS: Zika vírus, microcephaly, homeopathy, Helleborus niger, ABRAH

(C) International Journal of High Dilution Research.

Not for commercial purposes. 